\title{
KIOBEL'S BROADER SIGNIFICANCE: IMPLICATIONS FOR INTERNATIONAL LEGAL THEORY
}

\author{
By Austen L. Parrish*
}

The U.S. Supreme Court's decision in Kiobel v. Royal Dutch Petroleum Co. ${ }^{1}$ has ushered in a new era for human rights enforcement. Unanimously, the Court ended so-called foreigncubed human rights cases, that is, litigation where foreign plaintiffs sue foreign defendants for activity occurring abroad. The broadest form of universal civil jurisdiction that the Second Circuit's decision in Filártiga v. Peña-Irala ${ }^{2}$ once appeared to promise is over. Alien Tort Statute ${ }^{3}$ (ATS) litigation, while not foreclosed, has become more limited.

So far, the analysis of Kiobel has been doctrinal, focusing, for example, on whether the Supreme Court correctly applied the presumption against extraterritoriality. ${ }^{4}$ Alternatively, the commentary has been forward-looking, discussing the types of cases that will be seen after Kiobel ${ }^{5}$ or predicting the next battleground for human rights advocacy. ${ }^{6}$ For its part, the popular press has caricatured the decision either as representing the end to plaintiff's litigation run amok or as signaling the United States' deference to corporate interests over human rights interests. ${ }^{8}$

Kiobel, however, has broader significance. The decision reflects a rejection of attempts to reconceive global governance, from both left-leaning and right-leaning academics. In Kiobel,

* Interim Dean and Professor of Law, Southwestern Law School.

${ }^{1}$ Kiobel v. Royal Dutch Petroleum Co., 133 S.Ct. 1659 (2013).

2 Filártiga v. Peña-Irala, 630 F.2d 876 (2d Cir. 1980).

${ }^{3} 28$ U.S.C. $\$ 1350$.

${ }^{4}$ See, e.g., Anthony J. Colangelo, Kiobel: Muddling the Distinction Between Prescriptive and Adjudicative Jurisdiction, 28 MD. J. INT'L L. 65 (2013) (arguing that the Court misapplied the presumption); David L. Sloss, Kiobel and Extraterritoriality: A Rule Without a Rationale, 28 MD. J. INT'L L. 241 (2013) (discussing the presumption); see also Sarah Cleveland, Response: Plain Text, Stare Decisis, and Déjà Vu All over Again, SCOTUSBLOG (July 24, 2012), at http://www.scotusblog.com/2012/07/response-plain-text-stare-decisis-and-deja-vu-all-over-again (detailing the intent behind the ATS in a Kiobel symposium held prior to the Supreme Court decision).

${ }^{5}$ See generally Ingrid Wuerth, Kiobel v. Royal Dutch Petroleum Co.: The Supreme Court and the Alien Tort Statute, 107 AJIL 601 (2013) (describing what remains of the ATS after Kiobel); see also Oona Hathaway, Kiobel Commentary: The Door Remains Open to "Foreign Squared" Cases, SCOTUSBLOG (Apr. 18, 2013), at http://www. scotusblog.com/2013/04/kiobel-commentary-the-door-remains-open-to-foreign-squared-cases (concluding that "'foreign cubed' cases... are off the table" but predicting that other claims should remain viable); Curtis A. Bradley, Supreme Court Holds That Alien Tort Statute Does Not Apply to Conduct in Foreign Countries, ASIL INSIGHTS (Apr. 18, 2013), at http://www.asil.org.insights130418.cfm (noting the likely "significant reduction in international human rights litigation in U.S. courts").

${ }^{6}$ Christopher A. Whytock, Donald Earl Childress III \& Michael D. Ramsey, Foreword: After Kiobel_International Human Rights Litigation in State Courts and Under State Law, 3 U.C. IRVINE L. REV. 1, 4-6 (2013); cf. Austen L. Parrish, State Court International Human Rights Litigation: A Concerning Trend?, 3 U.C. IRVINE L. REV. 25, 25-26, 39-42 (2013) (describing the difficulties of state court human rights litigation).

7 See Beth Stephens, Kiobel Insta-Symposium: Closing Avenues for Relief, OPINIO JURIS (Apr. 24, 2013), at http:// opiniojuris.org/2013/04/23/kiobel-insta-symposium-closing-avenues-for-relief (describing how some "are crowing about the resounding defeat of rapacious trial lawyers who used these cases to shake down virtuous multinational corporations" and noting that little supports this characterization).

${ }^{8}$ See, e.g., Editorial, A Giant Setback for Human Rights, N.Y. TiMES, Apr. 18, 2013, at A26; Press Release, Human Rights First, Kiobel Ruling Undermines U.S. Leadership on Human Rights (Apr. 17, 2013), available at http:// www.humanrightsfirst.org/2013/04/17/kiobel-ruling-undermines-u-s-leadership-on-human-rights (noting that "the Supreme Court gutted the Alien Tort Statute"). 
the Court unanimously refused to adopt the unilateral approach encouraged by pluralists and other modern internationalists that would displace international multilateral approaches to global governance. The Court also did not fully embrace the perspective championed by international law skeptics, who would prefer that international norms have no role in U.S. jurisprudence. Justice Stephen Breyer's concurrence particularly reinforces the view that U.S. courts should heed international jurisdictional norms, while reaffirming that exorbitant assertions of extraterritoriality are disfavored-a position that is consistent with long-standing international law principles.

The Kiobel decision, then, is friendlier to international law than some have suggested. While Kiobel deprives advocates of one enforcement tool, the decision vindicates, rather than undermines, the interests of the human rights community. Kiobel suggests that efforts to build respect for human rights will need to occur multilaterally, instead of through unilateral extraterritorial regulation. If it spurs a reexamination of how to rebuild and legitimize international institutions, the decision's rejection of two popular theories in legal scholarship will be a welcome development.

\section{Rejecting Global Legal Pluralism}

The approach that the Court most roundly rejected is one that has been in ascendance among legal scholars recently: global legal pluralism. Legal pluralists have sought to take descriptive accounts from other disciplines, particularly sociology and anthropology, and turn them into normative theories for global governance. ${ }^{10}$ By staking a normative vision, they distinguish themselves from earlier pluralists who sought to better understand the world but not create an alternative jurisprudence. ${ }^{11}$ Unlike traditional international law scholars, pluralists contend that international norms in the age of globalization are best created and enforced at the substate level. ${ }^{12}$

Pluralists have sought, among other objectives, to change and redefine jurisdictional rules. ${ }^{13}$ They have sought to exploit, not resolve or manage, normative conflict and have attempted to expand jurisdictional bases to enable local courts to develop international law. Harold Koh's transnational legal process, while not defined as "pluralist," in many ways seeks to develop international law through substate actors in this way. ${ }^{14}$

9 Developments in the Law: Extraterritoriality, 124 HARV. L. REV. 1226, 1228 (2011) (describing how the "exceptionalism of extraterritoriality reflects the foundational ideals of the international state system").

${ }^{10}$ See, e.g., Paul Schiff Berman, Global Legal Pluralism, 80 S. CAL. L. REV. 1155, 1156 (2007) ("In sum, pluralism offers not only a more comprehensive descriptive account of the world we live in, but also suggests a potentially useful alternative approach to the design of procedural mechanisms, institutions, and practices.”).

${ }^{11}$ For an overview, see Ralf Michaels, Global Legal Pluralism, 5 ANN. REV. L. \& SOC. SCI. 243 (2009).

12 See e.g., Nico Krisch, Beyond COnstitutionalism: The Pluralist Structure of PostnaTiOnal LAW (2010); PAul SChiff Berman, Global Legal Pluralism: A Jurisprudence of LaW BEYOND BORDERS (2012).

${ }^{13}$ Nico Krisch, International Law in Times of Hegemony: Unequal Power and the Shaping of the International Legal Order, 16 EUR. J. INT'L L. 369, 403 (2005) (explaining how the United States "took an early lead in applying its own law to situations with little connection to itself other than a widely defined 'effect,' and it has succeeded in reshaping (or at least destabilizing) jurisdictional rules in this area”); see also Ruti G. Teitel, Humanity's Law: Rule of Law for the New Global Politics, 35 CORNELL INT'L L.J. 355, 355, 360-62 (2002) (describing a "juridical paradigm shift" and how humanitarian law has extended the scope of jurisdiction beyond national borders).

${ }^{14}$ Harold Hongju Koh, Transnational Public Law Litigation, 100 YALE L.J. 2347 (1991); see Paul Schiff Berman, The New Legal Pluralism, 5 ANN. REV. L. \& SOC. SCI. 225, 231-32 (2009) (describing Koh's work and its relationship to global legal pluralism). 
Yet global legal pluralism, as prescription, is no friend to international human rights. It rejects the universal norms upon which human rights depend and instead relies on domestic courts as experimentation sites where norms will develop and later migrate to the international system. This approach to global governance requires a unique faith that courts in other countries will interpret and develop human rights in a specific (and similar) way. But little suggests that this sort of consensus exists. ${ }^{15}$ The concern, then, is less that other nations will hale U.S. citizens into their courts for alleged violations ${ }^{16}$ but that other courts will develop norms of civil liability that are in tension, or are even inconsistent, with human rights. ${ }^{17}$ For these reasons, the pluralist recipe for promoting human rights everywhere will likely be (despite best intentions) counterproductive. ${ }^{18}$

Extraterritorial regulation of foreigners is problematic for other reasons too. Many view this kind of regulation as inherently illegitimate. ${ }^{19}$ Even if a substantive right could be universally agreed upon, procedural mechanisms for justice vary. Other nations view American adjudication skeptically and-rightly or wrongly-perceive American courts as biased, ${ }^{20}$ just as Americans often view foreign courts skeptically. ${ }^{21}$ Extraterritorial regulation of nonnationals is also seen as undemocratic ${ }^{22}$ and reflective of American exceptionalism and legal imperialism in its worst form. ${ }^{23}$

That Chief Justice John Roberts's majority opinion was unsympathetic to court-encouraged pluralistic approaches was unsurprising. ${ }^{24}$ But Breyer's concurrence also rejected them by failing to find that Congress had authorized universal civil jurisdiction. ${ }^{25}$ While Breyer would look to "international jurisdictional norms" to determine the ATS's reach, ${ }^{26}$ he was unwilling to

15 See Marko Milanović, Norm Conflict in International Law: Whither Human Rights?, 20 DUKE J. COMP. \& INT'L L. 69, 131 (2009) (noting that "it is quite naïve to think that general international law will always prevail over fragmentationist impulses"). For an account of how human rights developed from hard-fought political struggles and strategic alliances, see Yves Dezalay \& Bryant G. Garth, Constructing Law out of Power: Investing in Human Rights as an Alternative Political Strategy, in CAUSE LAWYERING AND THE STATE IN A GLOBAL ERA 354, 360 (Austin Sarat \& Stuart Scheingold eds., 2001).

${ }^{16}$ Kiobel v. Royal Dutch Petroleum Co., 133 S.Ct. 1659, 1669 (2013).

${ }^{17}$ Cf. Máximo Langer, The Diplomacy of Universal Jurisdiction: The Political Branches and the TransnationalProsecution of International Crimes, 105 AJIL 1 (2011) (describing the political aspects behind universal criminal jurisdiction).

18 See Bryant G. Garth, Rebuilding International Law After the September 11th Attack: Contrasting Agendas of High Priests and Legal Realists, 4 LOY. U. CHI. INT'L L. REV. 3, 8-9 (2006) (describing the potential of undermining the legitimacy of international norms).

${ }^{19}$ That the ATS has been employed generally against foreigners, but not against U.S. actors, increases the appearance of exceptionalism. James C. Hathaway, America, Defenders of Democratic Legitimacy?, 11 EUR. J. INT'L L. 121, 132 (2000) (noting how the "United States simultaneously asserts the right to lead, but also to be exempted from the rules it promotes").

${ }^{20}$ Kevin M. Clermont \& Theodore Eisenberg, Xenophilia in American Courts, 109 HARV. L. REV. 1120, 1121-22 (1996); Kimberly A. Moore, Xenophobia in American Courts, 97 NW. U. L. REV. 1497, 1503 (2003).

${ }^{21}$ See ERIC A. POSNER, THE PERILS OF GLOBAL LEGALISM 228 (2009) (suggesting that Americans only support decisions made by "American courts, which are staffed by Americans who share American values and interests").

${ }^{22}$ Austen L. Parrish, Reclaiming International Law from Extraterritoriality, 93 MINN. L. REV. 815, 859-64 (2009).

${ }^{23}$ Chandra Lekha Sriram, Human Rights Claims vs. the State: Is Sovereignty Really Eroding?, 1 INTERDISC. J. HUM. RTS. 107, 117 (2006) ("To the degree that proceedings take place only in the courts of powerful Western states, and often in those of former colonizers, the argument that cases are selective, and even driven by imperialistic agendas, can be and has been raised.").

${ }^{24}$ Kiobel v. Royal Dutch Petroleum Co., 133 S.Ct. 1659, 1664-65, 1668-69 (2013) (describing foreign policy concerns of imposing sovereign will onto conduct occurring within another sovereign's territorial jurisdiction).

${ }^{25}$ Id. at 1673-75 (Breyer, J., concurring); see also Wuerth, supra note 5, at 611-12.

${ }^{26}$ Kiobel, 133 S.Ct. at 1673 (Breyer, J., concurring). 
find that those norms permitted a free-for-all, where each nation's courts could claim authority to hear any case in the world. Both opinions relied on a more traditional territorial understanding "where distinct American interests [would need be] at issue" for jurisdiction to attach. ${ }^{27}$ Citing Justice Joseph Story, both the majority and Breyer's concurrence noted that Congress adopted the ATS when it was clear that " $[\mathrm{n}]$ o nation ha[d] ever yet pretended to be the custos morum of the whole world." 28

\section{Rejecting Sovereigntism}

Yet Kiobel was not a victory for right-leaning theorists either. Over the last fifteen to twenty years, a group of legal scholars (often referred to as international law skeptics or Sovereigntists) have attacked international law and its institutions, ${ }^{29}$ arguing that international law must be narrowly cabined to avoid undermining American interests. ${ }^{30}$ For Sovereigntists, international law usually undermines democratic sovereignty. They generally recoil when courts cite to foreign law $^{31}$ and oppose the creation of international institutions. From this perspective, ATS litigation constitutes an attempt by left-leaning groups to infuse internationalist values where they do not belong.

In many ways, the Sovereigntist position is an attempt to redefine and constrain the role of courts. Sovereigntists appear more animated by separation of powers and federalism concerns than by concerns over developing effective global governance. ${ }^{32}$

The Court, however, did not fully adopt or endorse the Sovereigntist approach. The majority came closest, with its invocation of legislative primacy. ${ }^{33}$ But the majority's application of the presumption against extraterritoriality was similar to how the Court has long approached jurisdictional rules. The Court was reluctant to assume that Congress had authorized the broadest reach of possible jurisdiction. ${ }^{34}$ The Court's majority opinion was consistent with

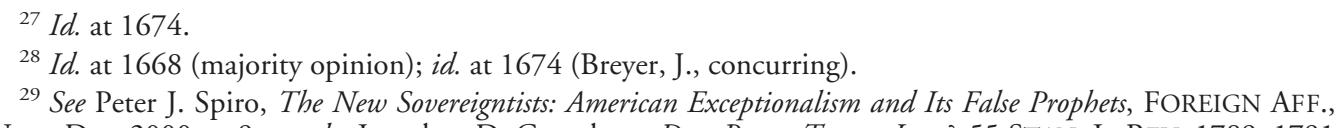
Nov.-Dec. 2000, at 9; see also Jonathan D. Greenberg, Does Power Trump Law?, 55 STAN. L. REV. 1789, 1791 (2003) (describing the differences between realists and liberal internationalists).

30 See, e.g., JACK L. GOLDSMITH \& ERIC A. POSNER, THE LIMITS OF INTERNATIONAL LAW 167-84, 225-26 (2005) (arguing that international law is often rhetorical and that "international law scholars exaggerate its power and significance"); POSNER, supra note 21, at ix-xvi, 28-39 (criticism of the expansion of global legalism and warning on the overreliance on international law and its institutions); Michael Stokes Paulsen, The Constitutional Power to Interpret International Law, 118 YALE L.J. 1762, 1804 (2009) ("The force of international law is thus largely an illusion ... [merely] a rhetorical, political trope ....").

${ }^{31}$ See Austen L. Parrish, Storm in a Teacup: The U.S. Supreme Court's Use of Foreign Law, 2007 U. ILL. L. REV. 637, 639-40, nn.8-10 (describing opposition to citation of foreign law).

${ }^{32}$ For a more in-depth discussion, see Parrish, supra note 22, at 822-27, 841-56.

${ }^{33}$ Cf. Lea Brilmayer, New Extraterritoriality: Morrison v. National Australia Bank, Legislative Supremacy, and the Presumption Against Extraterritorial Application of American Law, 40 S.W. L. REV. 655 (2011) (discussing the Court's focus on legislative supremacy and how the presumption permits judicial creativity).

${ }^{34}$ The Court often refuses to assume that Congress has utilized all jurisdictional power granted to it, even in the face of broad statutory language. See, e.g., Louisville \& Nashville R.R. Co. v. Mottley, 211 U.S. 149, 152-53 (1908) (interpreting the statutory grant of federal question jurisdiction to be narrower than what is constitutionally permitted); Strawbridge v. Curtiss, 7 U.S. (3 Cranch) 267, 267 (1806) (Marshall, C.J.) (interpreting the statutory grant of diversity jurisdiction to be narrower than constitutional limits). 
international law's respect for sovereignty and self-determination. ${ }^{35}$ Breyer's concurrence also was not sympathetic to the skeptics" view, as it sought to interpret the statute "consistent with international law and foreign practice." 36 In addition, the entire Court foreclosed only foreigncubed cases. Kiobel says little about how to decide ATS claims when significant ties to the United States exist. The least controversial claims from an international law perspectivethose seeking to hold U.S. actors liable for human rights violations, especially in places under U.S. control—should remain viable. ${ }^{37}$ For international law skeptics, Kiobel does little to insulate American jurisprudence from transnational norms. ${ }^{38}$

\section{Conclusion}

The doctrinal issues in Kiobel are important. The decision reflects culture-war-type debates over tort reform, the role of courts, separation of powers, and federalism. ${ }^{39}$ The case, however, also says something important about approaches to global governance. The decision may mark the beginning of a welcome retreat from a failed strategy of aggressive American unilateralism that has been promoted by both right-leaning and left-leaning academics.

Much work remains in the human rights area. Tremendous barriers to justice exist. International law and institutions remain underdeveloped, often to the benefit of multinational corporations and other actors. Our courts can and should play an important role in enforcing and developing international law, particularly to hold our own citizens accountable for human rights abuses (whether occurring in the United States or abroad). The hope after Kiobel is that the human rights community will turn away from unilateral enforcement and focus its attention on rebuilding international law and its institutions. In this way, Kiobel underscores the failings of two extremes in legal scholarship_ one that has sought to isolate internationalism, and another that has sought to privilege unilateralism. 